\title{
SEDIMENT BUDGETS BASED ON THE MASS OF SILT AND CLAY ON INTERTIDAL FLAT ADJACENT TO RIVER MOUTH
}

\author{
Fumihiko Yamada', Nobuhisa Kobayashi ${ }^{2}$, Yuichiro Shirakawa ${ }^{3}$, and Yoshihiro Sakanishi ${ }^{4}$ \\ Fine-grained sediment budgets based on the monthly bed level and net sediment flux monitoring during October 2006 \\ to October 2007 are estimated to examine the relative significance of tides and river discharges on mud transport on \\ an intertidal flat adjacent to a river mouth in the semi-closed sound. The intertidal flat accreted during normal \\ discharge conditions mainly due to the alongshore sediment flux toward the river mouth. However, the flat eroded \\ during large discharge conditions at the time of low tides. The offshore sediment transport during the large discharge \\ was four times larger than that during the normal discharge. The spatial variations of tidal currents cause alongshore \\ sediment fluxes toward the river mouth on the intertidal flat adjacent to the river mouth. The proposed fine-grained \\ sediment budgets are useful to understand and assess the transport pathways for silt and clay on the intertidal flat.
}

Keywords: sediment budget; fine-grained sediment; tidal flat; flux monitoring

\section{INTRODUCTION}

Intertidal flats are found on the fringe of many estuaries and coastlines world-wide. Intertidal flats are of great importance because they are host to diverse and productive ecosystem that supports higher organisms including wading birds, shellfish and fish stocks (Dyer, 2000). Intertidal flats also show dynamic morphologic changes and their inherent sensitivity to sea level changes calls for attention due to the possible future sea level rise caused by global warming (Andersen et al., 2006). The quantitative understanding of fine-grained (silt and clay) sediment budgets on intertidal flats is necessary for coastal protection and management.

The sediment budgets on the intertidal flats adjacent to the river mouth are influenced by processes with a range of timescales due to tides, wind waves, river discharges, and their interactions (Green and Coco, 2007; Le Hir et al., 2000; Yamada and Kobayashi, 2004; Yamada et al., 2009a, 2009b).

Sediment budgets also provide ways of describing the overall functioning of intertidal flats by ranking the relative importance of these diverse processes (e.g., Rodriguez and Dean, 2009). On the inner to outer continental shelves, there are growing number of studies focusing on the gravitationally forced transport of a thin layer of fluid mud (hyperpycnal layer) as the relative contributions of tides, wind waves, river discharges for the fine-grained sediment transport and budgets (e.g. Wheatcroft, 2000; Friedrichs and Wight, 2004; Harris, et al. 2008). On the intertidal flats, Malvarez, et al. (2004), Yamada \& Kobayashi (2009a, 2009b) investigated the effects of tide and wind waves on sediment transport and budgets. However, very little work is currently available on the effects of tide and river discharges on the fine-grained sediment budgets on the intertidal flats.

In this study, the effects of tides and river discharges for the fine-grained sediment transport and budgets were evaluated using field measurements and data analysis on an intertidal flat adjacent to the river mouth, located at the fetch-limited semi-closed Sound. Monthly bed level and net suspended sediment flux monitoring were conducted from October 2006 to October 2007. The bed levels were measured using an electric distance meter within an error of $2 \mathrm{~cm}$ described by Yamada and Kobayashi (2004) during low tides. Water level, flow velocities, and sediment concentrations were measured continuously on the flat. Monthly fine-grained sediment budgets based on the mass of silt and clay were used to interpret the suspended sediment transport pattern during the wet cycle. The proposed fine-grained sediment budgets are used to understand and assess the transport pathways for silt and clay on the intertidal flat.

\footnotetext{
${ }^{1}$ Graduate School of Kumamoto University, 2-39-1 Kurokami, Kumamoto, 860-8555,Japan

${ }_{2}^{2}$ Center for Applied Coastal Research, University of Delaware, Newark, Delaware 19716, U.S.A

${ }^{3}$ Nippon Koei, 4-2, Kohji, Chiyoda, Tokyo, 102-0083, Japan.

${ }^{4}$ Kajima, Akasaka, Minato-ku, Tokyo, 107-8502, Japan
} 


\section{FIELD SITE AND MEASUREMENTS}

The field site of this study is located on the center of the eastern coast of Ariake Bay in Japan, which is a closed inner bay. The length, width, and depth of the bay are approximately $97 \mathrm{~km}, 20 \mathrm{~km}$, and $20 \mathrm{~m}$, respectively. Fig. 1 depicts the field site at the mouth of the Shirakawa River. Yamada and Kobayashi (2004) presented the site characteristics including the oceanographic data such as the tide level, significant wave height and period, and wind velocity measured at an observation tower in 6.45 $\mathrm{m}$ depth of Kumamoto Port. The observation tower is located about $6 \mathrm{~km}$ south of the field site in this study. The datum of the water and land levels in this study is the Tokyo Peil datum in Japan. The tide is semidiurnal, and the mean spring tidal range is $3.86 \mathrm{~m}$. The average wave height and period are 0.2 $\mathrm{m}$ and $3 \mathrm{~s}$. The mudflat is composed of a mixture of sand, mud and organic matter. The median diameter is in the range of $0.10-0.18 \mathrm{~mm}$. The mud content is in the range $9.4-30.1 \%$. Mud is defined here as the sediments whose size is smaller than $0.075 \mathrm{~mm}$.

The water depth, velocity and suspended sediment concentration were measured at three points (A, $\mathrm{B}, \mathrm{C})$ along line R2 and at one point (D) along line R1. The cross-shore distance from the seawall is $500 \mathrm{~m}$ for point A (upper mid-tide zone), 1,040 m for point B (lower mid-tide zone), 1,520 m for point $\mathrm{C}$ (low-tide zone), and 1,040 $\mathrm{m}$ for point $\mathrm{D}$ (lower mid-tide zone). The water depth was measured using a pressure gauge. The fluid velocity at $10 \mathrm{~cm}$ above the bottom was measured by an electromagnetic current meter. The water depth and velocity were sampled continuously at a rate of $0.2 \mathrm{~s}$. The suspended sediment concentrations at 10 and $30 \mathrm{~cm}$ above the bottom were measured using two optical backscatter sensors, which were calibrated in a laboratory using the bottom sediment sampled from the measurement site (Yamada et al 2009a). The concentrations were sampled at a rate of $1 \mathrm{~s}$ for the duration of $20 \mathrm{~s}$ every $10 \mathrm{~min}$. The measurement duration at the four points are shown in Fig. 2. The pressure, velocity and concentration meters placed at point $A$ were moved to point $C$ and then to point $\mathrm{D}$. The intertidal flat is composed of a mixture of sand, mud and organic matter. The median diameter is in the range of $0.10-0.18 \mathrm{~mm}$. The content of mud defined as sediments of diameter less than $0.075 \mathrm{~mm}$ is about $30 \%$. The organic matter on the field site is about $2 \%$ (Yamada and Kobayashi, 2004). The mud mass per unit volume is about $400 \mathrm{~kg} / \mathrm{m}^{3}$. This value is used to convert the volume change to the mud mass change in the following.

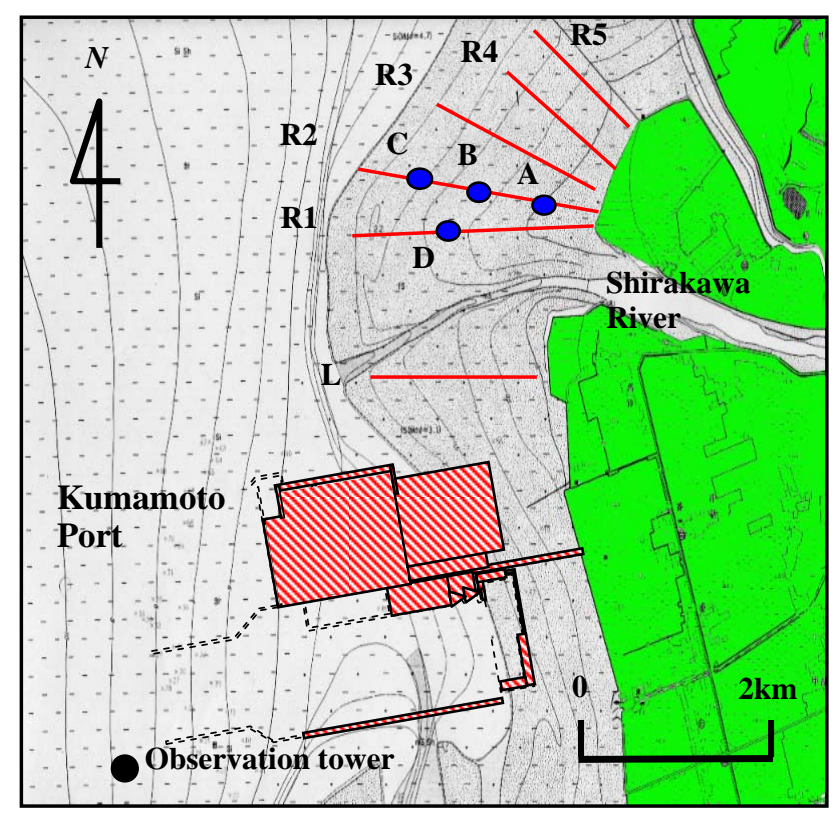

Fig. 1. Study area with bed level measurement lines L and R1 to R5 and point measurement locations A to D. 


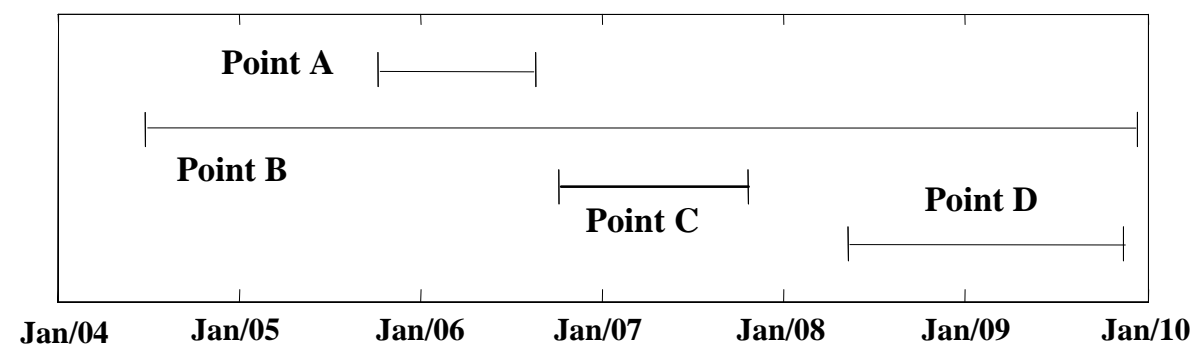

Fig. 2. The measurement duration at the four points

To fix a cross-shore profile line, square wooden stakes of $0.05-\mathrm{m}$ width and 2-m length were driven vertically $1.5 \mathrm{~m}$ below the tidal flat surface along lines L and R3 in Figure 2 in December 2000 and along lines R1, R2, R4, and R5 in March 2004. Local scour around the stake was limited to the area within a distance of $0.1 \mathrm{~m}$. The profile lines $\mathrm{L}$ and $\mathrm{R} 3$ consisted of 30 stakes spaced at an interval of $50 \mathrm{~m}$ and the total length was $1500 \mathrm{~m}$. The total lengths of the profile lines R1, R2, R4, and R5 with the stakes spaced at an interval of $80 \mathrm{~m}$ were $2240 \mathrm{~m}, 2080 \mathrm{~m}, 1520 \mathrm{~m}$, and $1520 \mathrm{~m}$, respectively. The bed levels at the specified cross-shore locations were measured from the crest of a seawall using an Electric Distance Meter (EDM) as explained by Yamada and Kobayashi (2004). The elevation of the EDM was obtained from a nearby benchmark. To measure the representative bed level in front of the wood stake, a large wood plate was placed on the mud surface. A reflector pole placed on the plate was used to measure the distance and angle between the EDM and the prism on the top of the pole. This survey method agreed with the conventional leveling method within an error of $2 \mathrm{~cm}$. The profile measurements were carried monthly during low water on days of spring tides. The survey was not conducted under water but extended close to the mean monthly-lowest water level.

The measured monthly cross-shore profiles along six lines during May 2004 to December 2009 are averaged and presented in the top panel of Fig. 3. The mean sea level (MSL) is $0.14 \mathrm{~m}$ above the datum of the bed level. The mean high water (MHW) and mean low water (MLW) during neap (N) and spring (S) tides are indicated in Fig. 3. The horizontal distance was measured from the vertical seawall located along the shore. The mean high water spring (MHWS) is $1.93 \mathrm{~m}$ but not shown in Fig. 3 because the entire intertidal flat is below the mean high water neaps (MHWN=0.77 $\mathrm{m}$ ). These profiles were slightly convex upward and the average slopes were in the range of $1 / 700-1 / 1,200$. The bed elevation of the R profiles increased toward the Shirakawa River, implying deposition of sediments transported in the river at its mouth. The measured 66 cross-shore profiles along line R2 from May 2004 to December 2009 are shown in the bottom panel of Fig. 3. Only the bed level survey points located between 100 and 1,700 m from the seawall could be measured always because the bed surface within $100 \mathrm{~m}$ from the seawall and farther offshore was too soft sometimes. The fluctuations of the measured bed level increased offshore, indicating the increase of the bottom elevation change with the offshore increase of the wet duration. The shape of the measured profiles was convex upward, unlike the concave upward profile of sandy beaches.

The temporal variations of the vertical displacement parameter at the R lines are shown in Fig. 4. This parameter introduced by Yamada and Kobayashi (2004) is defined as the average deviation of each measured profile from the average profile and expresses the average vertical accretion (positive) or erosion (negative) depth in the cross-shore direction. The sudden decrease of about $0.3 \mathrm{~m}$ in September 2005 may have been caused by dredging of $86,000 \mathrm{~m}^{3}$ for the maintenance of the navigation channel at the Shirakawa River mouth in July 2005. This dredged sediment volume approximately corresponds to the annual sediment yield of the Shirakawa River (Kuriyama and Hashimoto 2004). The vertical displacement parameters became the minimum in December 2005 and appeared to have reached a new quasi-steady state. Additional dredging of $43,000 \mathrm{~m}^{3}$ was conducted in the same area in July 2008 but its effect is not apparent in Fig. 4. The fine-grained sediment budgets are estimated during October 2006 to October 2007 in the following to minimize the dredging effects. The field measurements were conducted only at point B in September 2005 (see Fig. 2). The velocity and concentration measurements at point B during July to September 2005 were examined carefully but did not reveal anything unusual. 

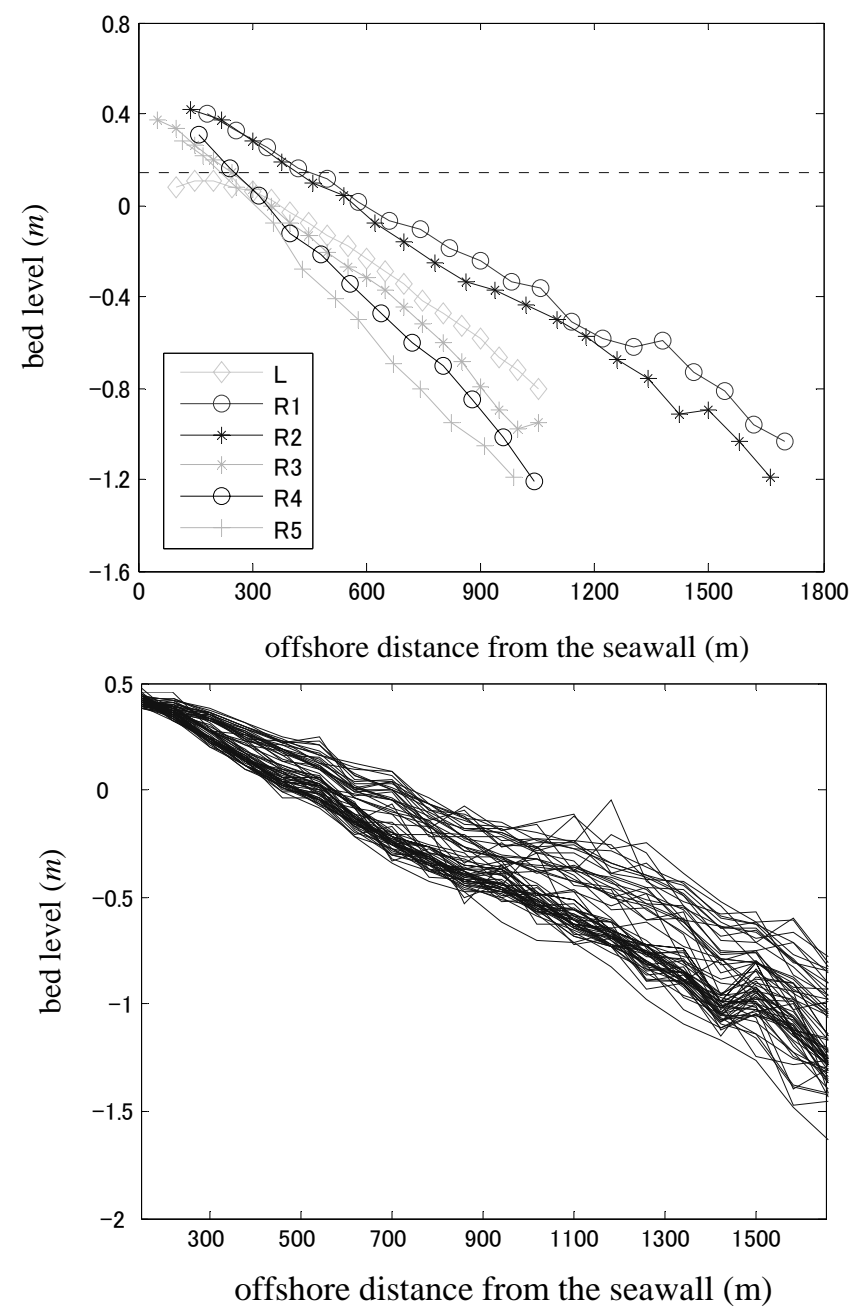

Fig. 3. Average cross-shore profiles along six lines (top) and all measured profiles along line R2 (bottom).

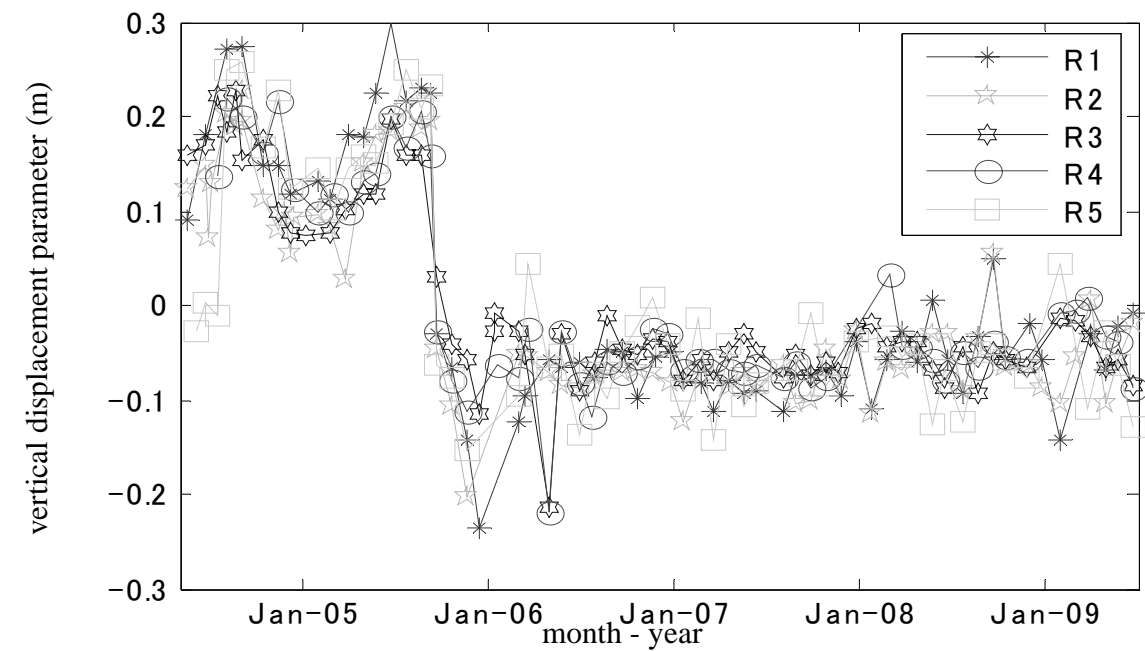

Fig. 4. Temporal variations of vertical placement parameters along five lines from June 2004 to September 2009. 


\section{PHASE AVERAGED WATER AND SEDIMENT FLUXES}

The measured pressure was converted to the free surface elevation using linear wave theory. The water depth $h$ was obtained as the vertical distance from the local bottom to the free surface. The measured velocity vector at $10 \mathrm{~cm}$ above the bottom was separated into the cross-shore (west to east) velocity $u$ and the longshore (south to north) velocity $v$. The measured concentrations at 10 and $30 \mathrm{~cm}$ were almost the same (Yamada et al. 2009a) and the concentration $C$ at $10 \mathrm{~cm}$ above the bottom is simply assumed to be approximately the same as the depth-averaged concentration in the following analysis.

The measured time series of $h, u$ and $v$ are expressed as $h=\left(\bar{h}+h_{w}\right), u=\left(\bar{u}+u_{w}\right)$ and $v=\left(\bar{v}+v_{w}\right)$, where the overbar indicates time averaging over the duration of $20 \mathrm{~s}$ used for the suspended sediment concentration measurement. The subscript $w$ indicates the wave component and the time-averaged values of $h_{w}, u_{w}$ and $v_{w}$ are zero. The measured concentration $\mathrm{C}$ varied little over 20 s and is represented by the time-averaged concentration $\bar{C}$ which includes the effects of the waves and river discharge. The measured suspended sediment concentrations were high during storms with large wave heights and when the river discharge was large. The measured velocities $u$ and $v$ are assumed to be approximately the same as the depth-averaged cross-shore and longshore velocities. The 20-s averaged water fluxes are expressed as $\overline{h u}$ and $\overline{h v}$. The wave-induced fluxes $\overline{h_{w} u_{w}}$ and $\overline{h_{w} v_{w}}$ are found to be negligible because of the small waves at this site (Yamada et al. 2009a). As a result, the 20-s averaged water fluxes are represented by $\bar{h} \bar{u}$ and $\bar{h} \bar{v}$. The 20-s averaged suspended sediment fluxes are expressed as $\bar{h} \bar{u} \bar{C}$ and $\bar{h} \bar{v} \bar{C}$.

The temporal variations of the 20-s averaged fluxes are plotted as a function of time $t$ for each wet tidal cycle whose duration is denoted as $T$. The number of wet cycles analyzed at points A, B, C and D are listed in Table 1. The mean wet duration is the average value of $T$. The typical variation during one wet cycle is obtained by phase averaging where the phase during one wet cycle is identified using the normalized time $t_{*}=\left(t-t_{1}\right) / T$ with $t_{1}=$ beginning time for the wet cycle. The water fluxes $\bar{h} \bar{u}$ and $\bar{h} \bar{v}$ at given phase $t_{*}$ are averaged for all the wet cycles analyzed at each point. The phaseaveraged water fluxes during one wet tidal cycle at points A, B, C, and D are plotted in the top panels of Fig.3. The water fluxes at points A, B, and $\mathrm{C}$ were onshore during the flood tide, in the southwest direction during the high tide, and offshore during the ebb tide. However, the water flux at point $\mathrm{D}$ was in the opposite direction throughout the wet cycle and was approximately three times smaller than the fluxes at the other three points.

The suspended sediment fluxes $\bar{h} \bar{u} \bar{C}$ and $\bar{h} \bar{v} \bar{C}$ at given phase are averaged for all the wet cycles at each point. The phase-averaged suspended sediment fluxes during one wet tidal cycle at points A, B, C, and D are plotted in the bottom panels of Fig. 5 and in vector form in Fig.6. The suspended sediment fluxes and the corresponding water fluxes turn out to be similar because the suspended sediment mass $\bar{h} \bar{C}$ did not change much during one wet cycle at this field site (Yamada et al. 2009b). The phase-averaged suspended sediment flux at point $\mathrm{D}$ was mostly northward unlike the suspended sediment fluxes at points A, B, and C which were mostly southward towards the Shirakawa River. 

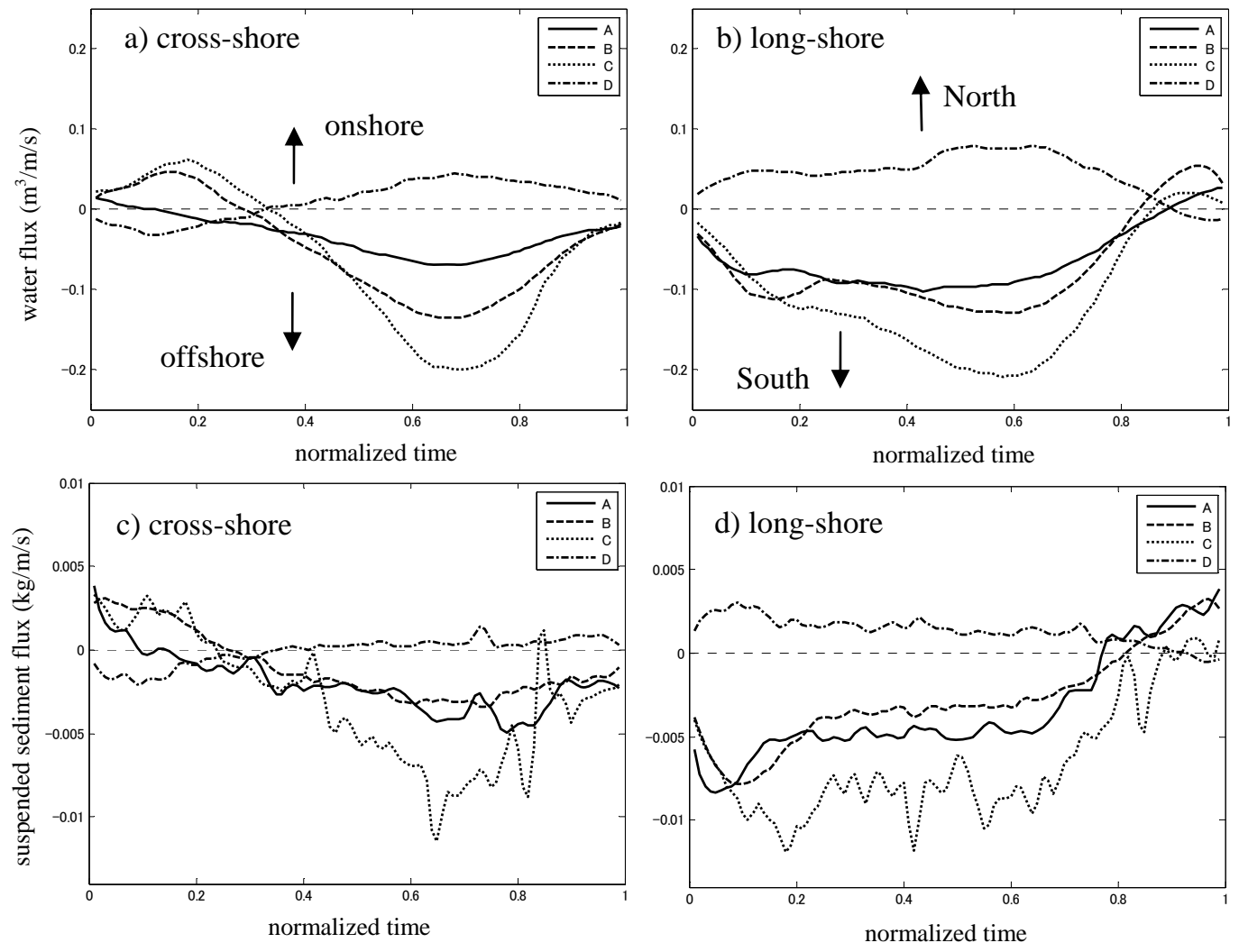

Fig. 5. Phase-averaged (a) cross-shore water fluxes; (b) long-shore suspended sediment fluxes; (c) cross-shore suspended sediment fluxes; (d) long-shore suspended sediment fluxes during one wet cycle at points A, B, C and D.
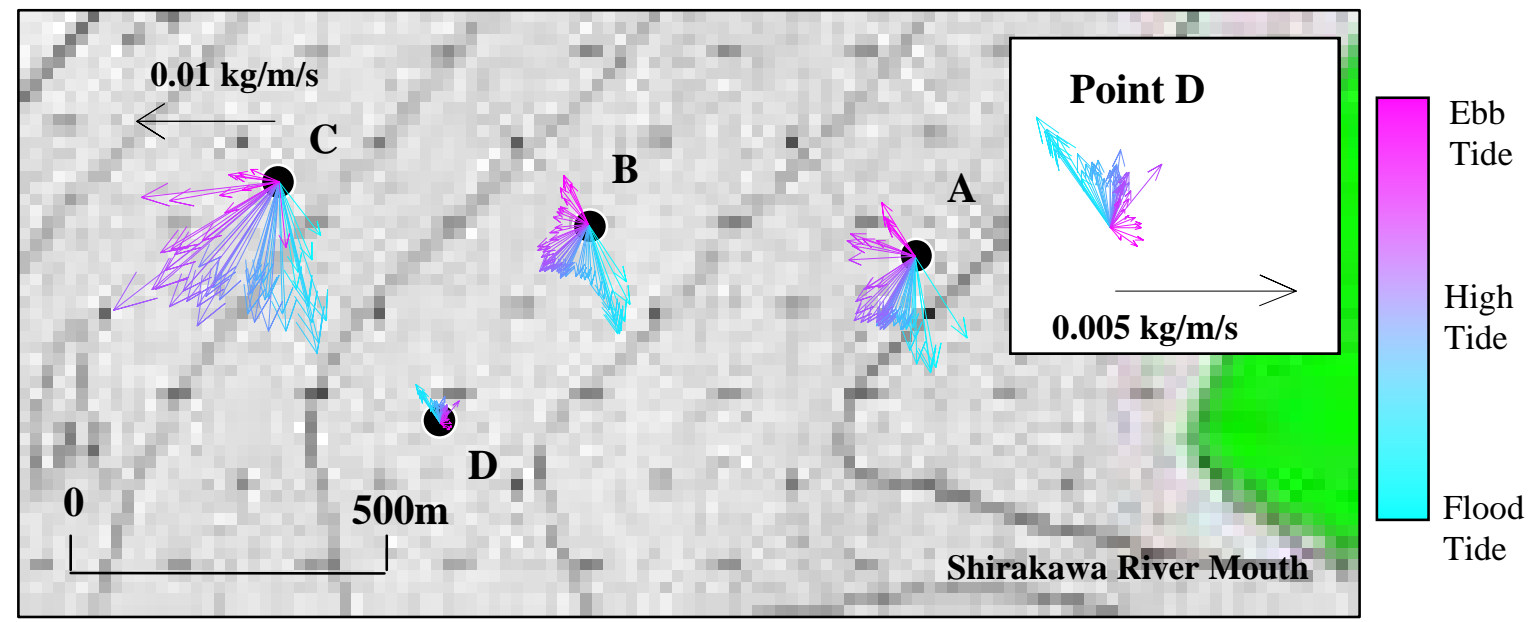

Fig. 6. Variation of phase-averaged suspended sediment flux in vector form during one wet tidal cycle relative to local depth contour at points A, B, C and D (enlarged in top right corner). 


\section{MUD MASS BUDGET}

To evaluate the effects of tides and river discharge on the fine-grained sediment transport and budgets on the intertidal flat adjacent to the Shirakawa River mouth, monthly fine-grained sediment budgets are estimated using the field data during October 2006 to October 2007. The intertidal flat is divided into the north and south areas separated along line R2 as shown in Fig. 7. The monthly finegrained sediment budgets for the two areas are expressed as

$$
\begin{array}{lll}
\text { North area: } & Q_{A 1}=Q_{N}-Q_{W 1}-Q_{S} & \text { (unit: } \mathrm{kg} / \mathrm{month} \text { ) } \\
\text { South area: } & Q_{A 2}=Q_{S}-Q_{W 2}+a \cdot Q_{R} & \text { (unit: } \mathrm{kg} / \mathrm{month} \text { ) }
\end{array}
$$

where $Q_{A 1}$ and $Q_{A 2}$ are the mass of silt and clay deposited (positive) or eroded (negative) in the north and south areas, respectively. $Q_{N}$ and $Q_{S}$ is the mass of silt and clay transported through line R5 and R2, respectively. $Q_{W 1}$ and $Q_{W 2}$ are the mass of silt and clay transported offshore from the north and south areas, respectively. $Q_{R}$ is the mass of silt and clay transported from the river to its mouth. The unknown coefficient $\boldsymbol{a}$ is used to find a fraction of $Q_{R}$ contributing to the sediment budget in the south area. The arrows in Fig.7 depict the positive directions of the mass fluxes. No sediment is assumed to be transported through the onshore boundary of the seawall. $Q_{A 1}$ and $Q_{A 2}$ are calculated using the monthly bed level monitoring results and the sediment mass per unit volume of $400 \mathrm{~kg} / \mathrm{m}^{3} . Q_{W 1}$ and $Q_{S}$ are estimated using the sediment flux measurements at points $\mathrm{C}$ and $\mathrm{B}$ as indicated in the left panel of Fig. 7. $Q_{N}$ is determined using Eq. (1). $Q_{R}$ is estimated using an empirical equation between $Q_{R}$ and the river discharge (Kuriyama and Hashimoto 2004; Yamada et al. 2010). The unknown values of $Q_{w 2}$ and $a$ are estimated by minimizing the squared error of the measured and estimated $Q_{A 2}$ using Eq. (2).

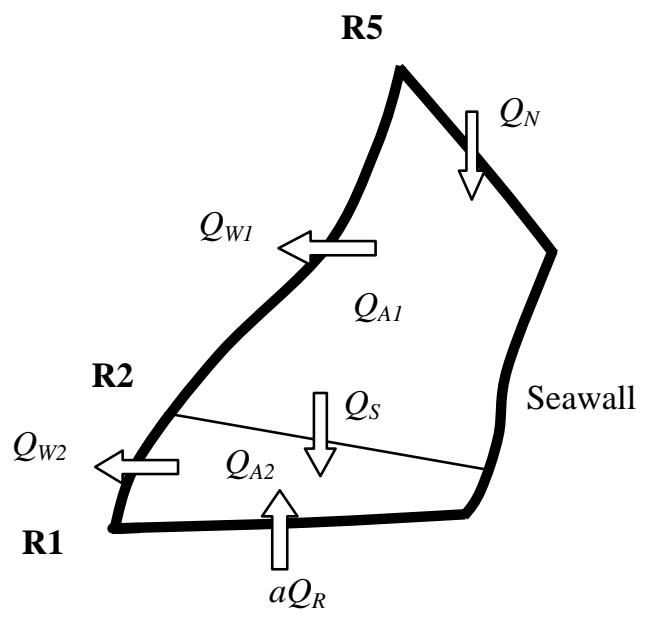

Fig. 7. Variables setting for mud mass budget with an arrow indicating the positive direction of each mud flux.

Fig. 8 shows the cells with the bed level measurement points used to calculate the silt and clay mass $Q_{A 1}$ and $Q_{A 2}$ deposited in the north and south areas. The boundary lengths in Fig. 8 are as follows: $l_{N}=748 \mathrm{~m} ; l_{W 1}=1,380 \mathrm{~m} ; l_{W 2}=306 \mathrm{~m} ; l_{S}=1,440 \mathrm{~m} ; l_{E 1}=617 \mathrm{~m}$; and $l_{E 2}=145 \mathrm{~m}$. The north area is $0.76 \mathrm{~km}^{2}$ and the south area is $0.28 \mathrm{~km}^{2}$. Each cell includes one bed level measurement point and the bed level in the cell is assumed to change uniformly. The volume change in each area is the sum of the cell volume changes. The monthly volume change is converted to the monthly mass change. It should be stated that the suspended sediment flux $Q_{w 1}$ along $l_{W 1}$ is crudely assumed to be represented by the flux measurement at point C. The suspended sediment flux $Q_{s}$ along $\mathrm{R} 2$ are represented by the measurements at points $\mathrm{B}$ and $\mathrm{C}$. 
- $\quad$ Bed level measurement point

\section{R5}

Suspended sediment flux measurement point
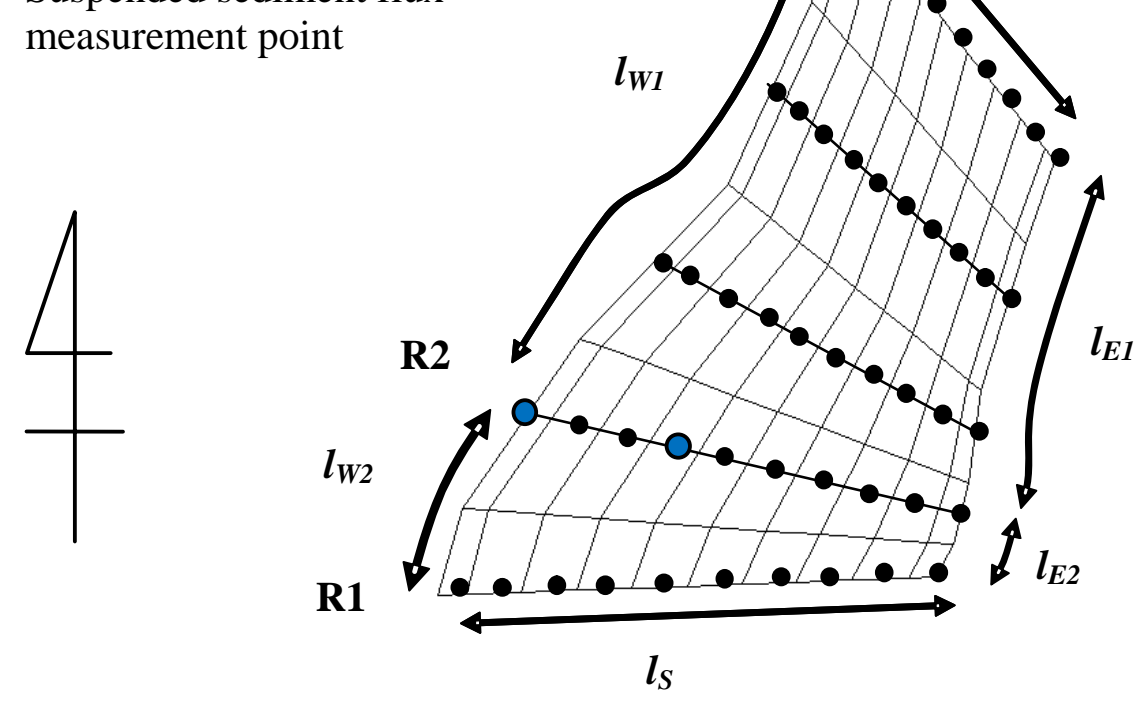

Fig. 8. Cells used for calculation of silt and clay mass $Q_{A 1}$ and $Q_{A 2}$ deposited in north and south areas, respectively.

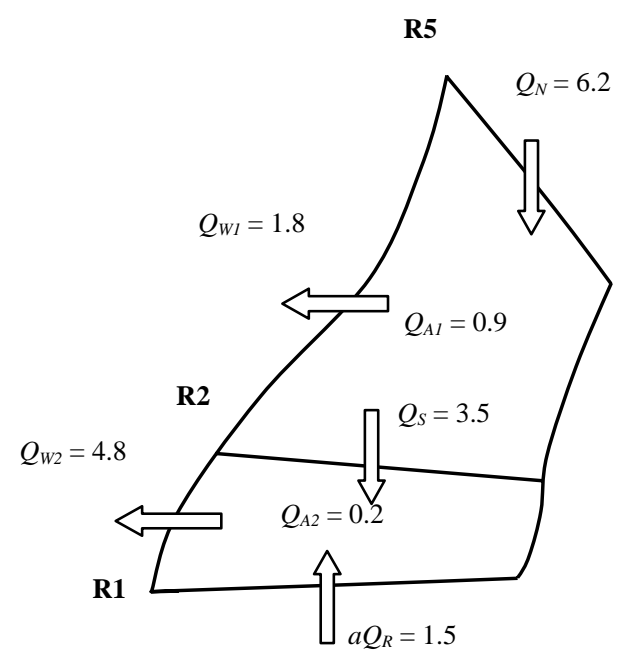

(a) Normal condition
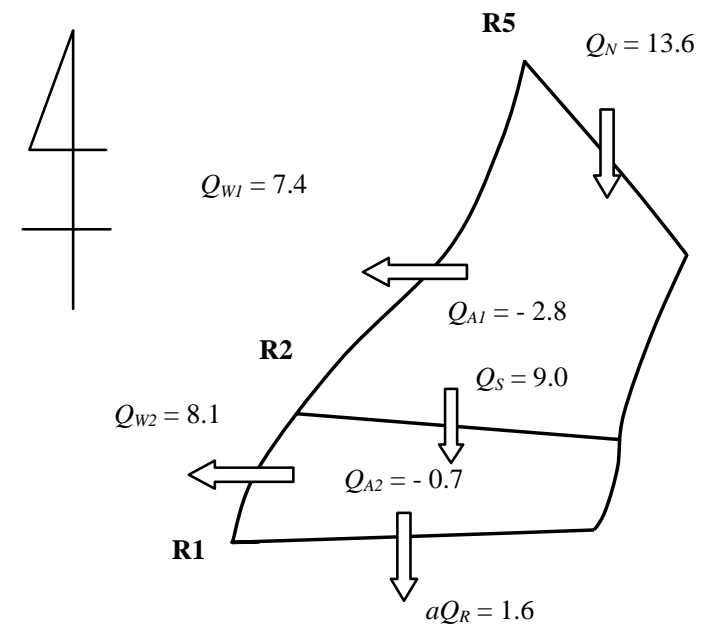

(b) Episodic events (River flashing)

Fig. 9. Month-averaged sediment budgets during the non-flood period (left) and the flood period (right): The unit of mud flux is $1.0 \times 10^{6}(\mathrm{~kg} /$ month). 
$Q_{R}$ is calculated using the empirical relationship between the suspended sediment concentration and Shirakawa river discharge proposed by Kuriyama and Hashimoto (2004). Two peaks in July 2006 and 2007 corresponded to the river discharge exceeding 1,200 $\mathrm{m}^{3} / \mathrm{s}$. Although the fine-grained sediments in the north area were eroded, those in the south area were almost in equilibrium. All the time series of estimated sediment budgets were averaged during normal and storm durations. Fig. 9 shows month-averaged sediment budgets during the non-flood period (left panel) and the flood period (right panel). During the normal conditions, both areas accreted because of the inflow of $Q_{N}$ and $Q_{R}$. However, during the episodic events, both areas eroded due to the increase of offshore fluxes $Q_{W 1}$ and $Q_{W 2}$. As a result, the net fluxes of suspended sediment at points A, B, C along line R2 (Fig. 6) and the alongshore fine-grained sediment fluxes $Q_{N}$ and $Q_{S}$ (Fig. 9) were directed toward the south. The reason for this dominant southward transport is inferred using available oceanographic data.

$\mathrm{HF}$ radar has been gaining recognition as an efficient and effective method of measuring surface currents of high temporal and special resolution in large coastal areas (e.g., Parks et al. 2009). Four HF radar stations were installed along the coast of Ariake Sound in 2005 and hourly measured tidal surface currents have been available since April 2006. The horizontal distributions of measured average currents during February to May 2009 are shown in Fig. 10. The surface (mostly tidal) currents were directed south or southeast offshore of the field site. Consequently, the dominant direction of the alongshore suspended sediment transport on this intertidal flat is related to the tidal current pattern offshore of the field site.

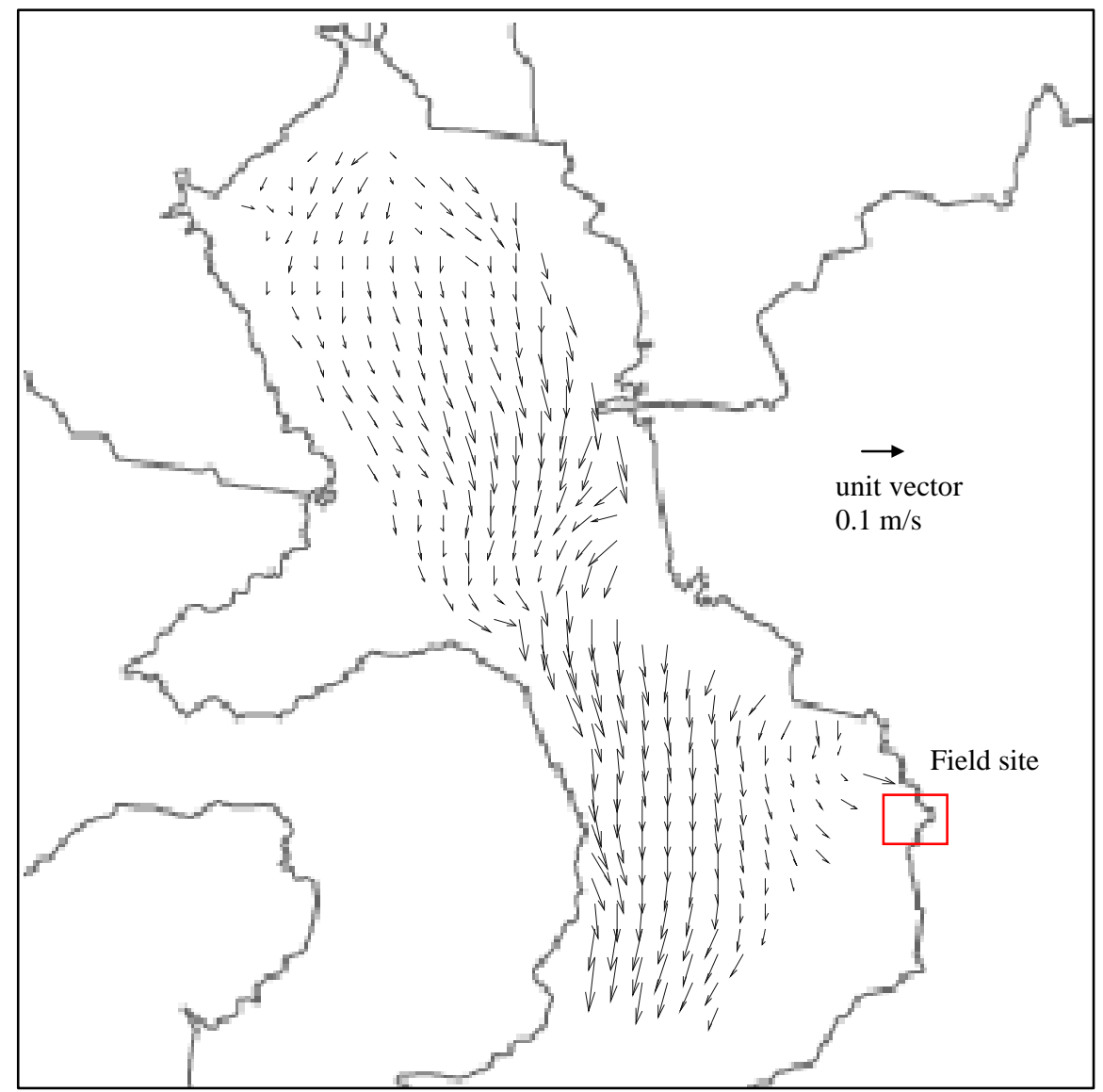

Fig. 10. Horizontal distribution measured by HF radar of average tidal velocity during February to May 2009 (bottom). 


\section{SUSPENDED SEDIMENT FLUX AT POINT D}

The sediment budget indicated that both areas accreted due to the influxes of $Q_{N}$ and $\boldsymbol{a} Q_{R}$ with $\boldsymbol{a}=$ 0.14 during the normal seasons. However, during rainy seasons, both areas were eroded due to the increase of the offshore fluxes $Q_{W 1}$ and $Q_{W 2}$ where $\boldsymbol{a} Q_{R}$ with $\boldsymbol{a}=-0.0004$ was small and the river sediment flux $Q_{R}$ appeared to have been flushed offshore through the navigation channel. Here, measured suspended sediment flux at point D was examined from May 2008 to October 2009 and compare with estimated $\boldsymbol{a} Q_{R}$. As shown in the top panel of Fig. 11, two large river discharges were occured at June 2008 and July 2009. Although two peaks were similar, the measured directions of suspended sediment flux at point D were different. The measured flux direction during June 2008 was consistent with the estimated $\boldsymbol{a} Q_{R}$ as shown in Fig. 6. However, the measured flux direction during July 2009 was opposite direction in the bottom panel of Fig. 11.

Fig. 12 shows measured time series of tide level and river discharge during the flood periods. As shown in the top panel, the peak of river discharge on 11 June 2008 was occurred during low tide. Because of emergence of tidal flats, the flooding river water did not flow over the intertidal area. On the other hands, the peak on 24 July 2008 was occurred during high to ebb tide. Therefore, the phase relationships between tide level and the peak of river discharge would be important for the water and sediment transport directions on the intertidal flat adjacent to river mouth.

Fig. 13 shows the comparison of measured longshore velocity during one tidal cycle at point $\mathrm{D}$ on June 2008 and November 2008. During the flood period, longshore velocity moves toward south direction (outflow) at point D as shown in left panel of Fig. 13. However, longshore velocity toward north direction (inflow) is dominant during normal conditions. This finding corresponds to the sediment budget results described above.

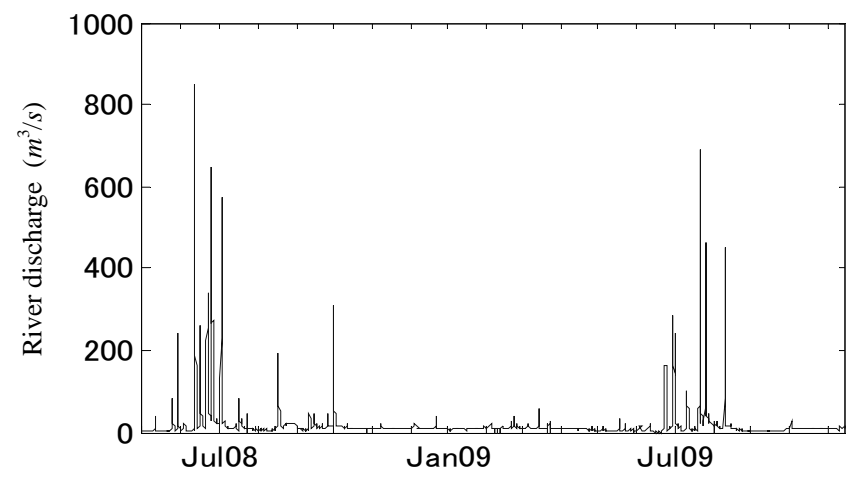

a) river discharge

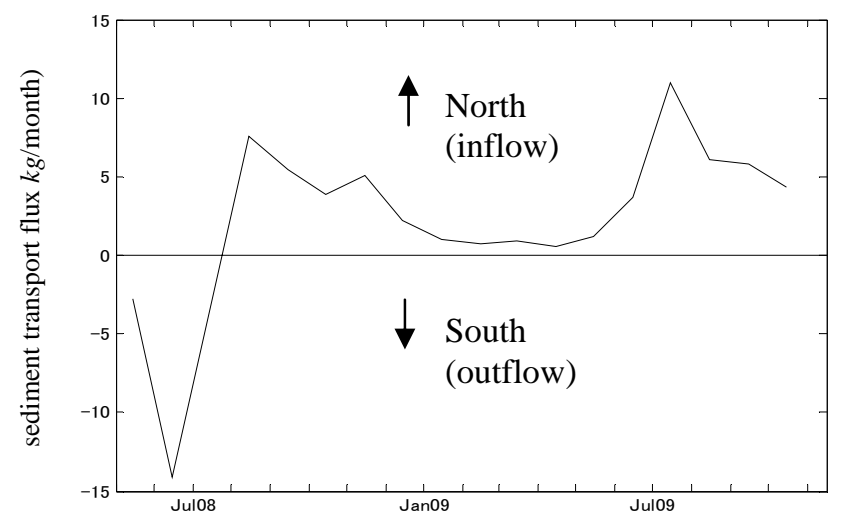

Fig. 11. River Discharge and sediment transport flux at point D during from May 2008 to October 2009 

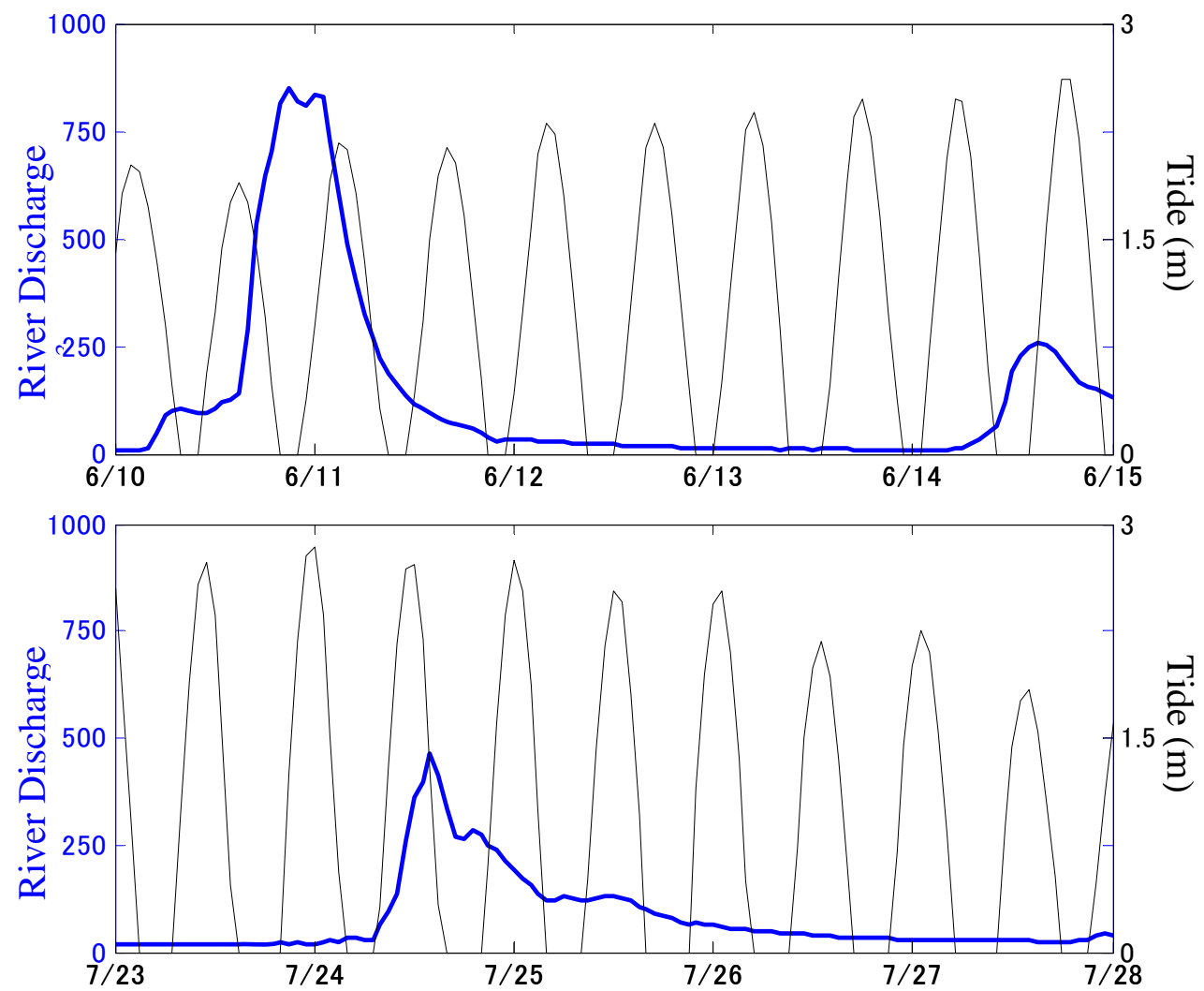

Fig. 12. Measured time series of tide level and river discharge during flood periods during 10 June 2008 to 15 June 2008 (top) and during 23 July 2009 to 28 July 2009 (bottom)

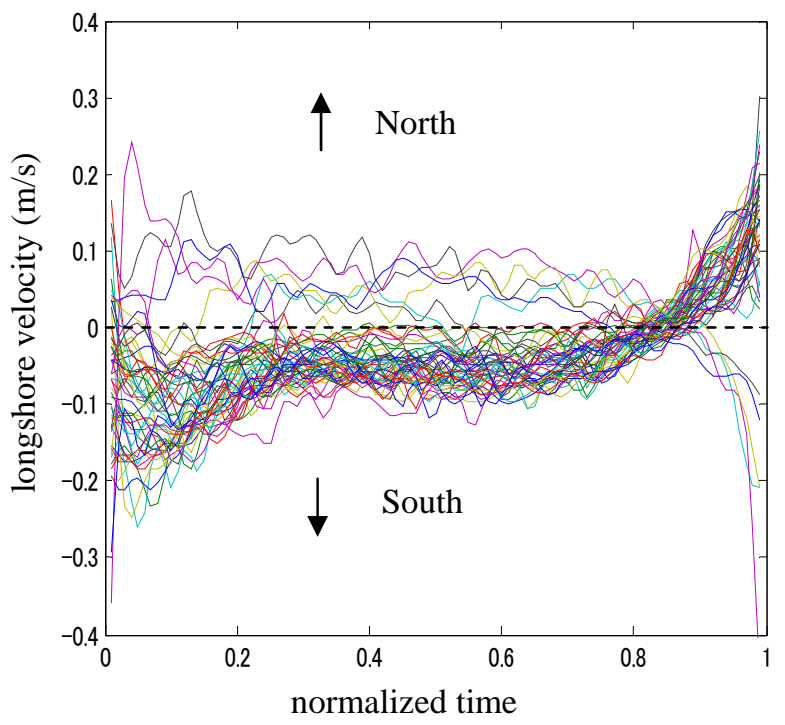

a) June 2008 (flood period)

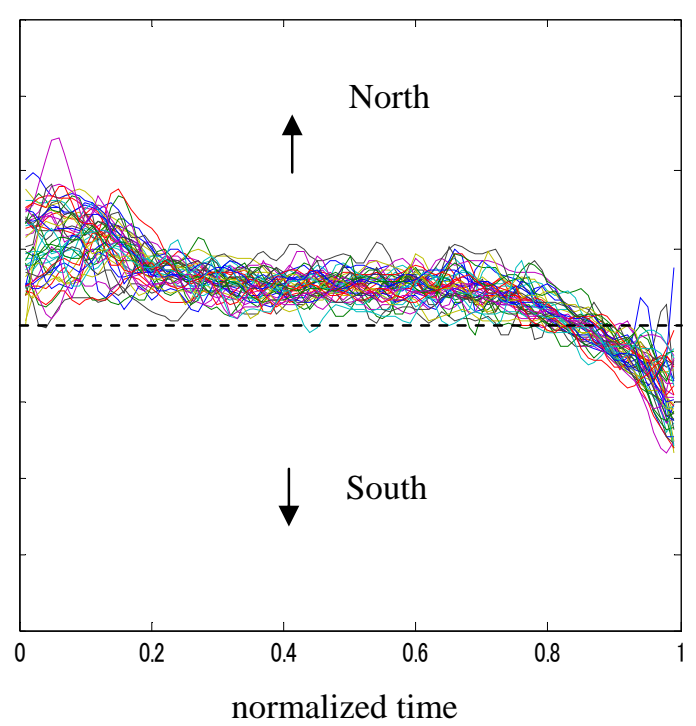

b) November 2008 (normal condition)

Fig. 13. Superimposed longshore velocities during one tidal cycle at point D on June 2008 (left) and November 2008 (right) 


\section{CONCLUSIONS}

To estimate the monthly sediment budget of silt and clay mass on an intertidal flat adjacent to Shirakawa River mouth, monthly bed level and net sediment flux monitoring were conducted from October 2006 to October 2007. Currents offshore of the field site are obtained using HF radar data. The intertidal flat accreted during normal discharge conditions mainly due to the alongshore sediment flux toward the river mouth. However, the flat eroded during large discharge conditions $\left(1,200 \mathrm{~m}^{3} / \mathrm{s}\right)$ at the time of low tides. The offshore sediment transport during the large discharge was four times larger than that during the normal discharge. The alongshore sediment flux toward the river mouth on the intertidal flat appears to be related to the offshore surface current pattern measured by the HF radar. The findings of this study may be specific to this intertidal flat but the adopted comprehensive approach may be applicable to other intertidal flats.

\section{ACKNOWLEDGMENTS}

This study was supported by a Grant-in-Aid for Scientific Research by the Japan Society for the Promotion of Science.

\section{REFERENCES}

Andersen, T. J., Pejrup, M., and Nielsen, A. A. (2006). ”Long-term and high-resolution measurements of bed level changes in a temperate, microtidal coastal lagoon.” Mar. Geol., 226(1-2), 115-125.

Dyer, K. R., Christie, M. C., and Wright, E. W. (2000). "The classification of intertidal mudflat.” Cont. Shelf Res., 20(10-11), 1039-1060.

Friedrichs, C. T., and Wright, L. D. (2004). "Gravity-driven sediment transport on the continental shelf: implications for equilibrium profiles near river mouths.” Coastal Eng., 51(8-9), 795-811.

Green, M. and Coco, G. (2007). "Sediment transport on an estuarine intertidal flat: measurements and conceptual model of waves, rainfall and exchanges with a tidal creek.” Estuarine, Coastal and Shelf Sci., 72(4), 553-569.

Giardino, A., Ibrahim, E., Adam, S., Toorman, E. A., and Monbaliu, J. (2009). "Hydrodynamics and cohesive sediment transport in the Ijzer estuary, Belgium: case study.” J. of Waterw., Port, Coastal and Ocean Eng., 135(4), 176-184.

Harris, K. C., Sherwood, C. R., Signell, R. P., Bever, A. J., and Warner, J. C. (2008). "Sediment dispersal in the northwestern Adriatic Sea." J. of Geophys. Res., 113, C11S03, doi:10.1029/2006JC003868.

Kuriyama, Y. and Hashimoto, K. (2004). "Sediment budget on an intertidal flat at the mouth of the Shirakawa River, Japan.” Technical Note of Port and Airport Research Institute, Yokosuka, Japan, 1074, 1-16.

Le Hir, P., Roberts, W., Cazaillet, O., Christie, M, Bassoullet, P., and Bacher, C. (2000). "Characterization of intertidal flat hydrodynamics.” Cont. Shelf Res., 20(12-13), 1433-1459.

Malvarez, G., Navas, F., and Jackson, D. W. T. (2004). "Investigations on the morphodynamics of sandy tidal flats: a modeling application.” Coastal Eng., 51(8-9), 731-747.

Parks, A. B., Shay, L. K., Johns, W. E., Martinez-Pedraja, J., and Gurgel, K. W. (2009). "HF radar observations of small-scale surface current variability in the Straits of Florida.” J. of Geophys. Res., 114, C08002, doi:10.1029/2008JC005025.

Patchineelam, S. M., Kjerfve, B., and Gardner, L. R. (1999). “A preliminary sediment budget for the Winyah Bay estuary, South Carolina, USA.” Mar. Geol., 162(1), 133-144.

Pedersen, J. B. T., and Bartholdy, J. (2006). "Budgets for fine-grained sediment in the Danish Wadden Sea.” Mar. Geol., 235(1-4), 101-117.

Rodriguez, E. Z. and Dean, R. G. (2009). “A sediment budget analysis and management strategy for Fort Pierce Inlet, Florida.” J. of Coastal Res., 25(4), 870-883. 
Yamada, F. and Kobayashi, N. (2004). “Annual variations of tide level and mudflat profile.” J. of Waterw., Port, Coastal and Ocean Eng., 130(3), 119-126.

Yamada F., Kobayashi, N., Sakanishi, Y. and Tamaki, A. (2009a). "Phase averaged suspended sediment fluxes on intertidal mudflat adjacent to river mouth.” J. of Coastal Res., 25(2), 350-358.

Yamada F., Kobayashi, N., Sakanishi, Y. , Shirakawa, Y., and Payo, A. (2009b). "Suspended sediment fluxes due to tides and waves on meso-tidal flat.” Proc. of 31st International Conference on Coastal Eng., World Scientific, Singapore, 1990-2002.

Wheatcroft, R. A. (2000). “Oceanic flood sedimentation: a new perspective.” Cont. Shelf Res., 20(16), 2059-2066. 